\title{
Appetite Stimulants Use in Cystic Fibrosis
}

Key words: cystic fibrosis; appetite stimulants; megestrol acetate; cyproheptadine hydrochloride; dronabinol; antipsychotic drugs; antidepressants; recombinant human growth hormone; anabolic androgenic steroids.

\section{INTRODUCTION}

The fundamental nutritional goal for cystic fibrosis (CF) is to achieve normal growth and development and, once genetic potential is reached, to maintain good nutritional status throughout life. Evidence has shown that lung function is closely associated with nutritional status in $\mathrm{CF}^{1-3}$ and that nutritional status is an independent predictor of survival. ${ }^{4}$ Despite this knowledge, a large proportion of the $\mathrm{CF}$ population still is not able to achieve this nutritional goal. Epidemiological studies from the USA have revealed three times the expected prevalence of $\mathrm{CF}$ patients below the 10th percentile for height and weight. ${ }^{5}$

Good nutritional status is dependent on the consumption of adequate nutrients, which is driven by complex, inter-related factors such as physical hunger, appetite, food-related behaviors, emotions, knowledge, and beliefs. Table 1 focuses on multiple issues possibly contributing to poor appetite or poor food intake in CF. Some of these factors are directly related to $\mathrm{CF}$ and others are not but may be more prevalent in people with CF because of the impact of the disease or the treatments on overall well-being.
There are several phases to food intake. First, there is the gastric motility phase which is mediated by the vagus afferents. This is followed by the post absorptive phase which is mediated by the duodenal release of cholecystokinin (CCK). Other hormones that are released include ghrelin, and peptide YY3 (PYY). CCK promotes satiety and slows gastric emptying by contracting the pyloric sphincter. Ghrelin signals hunger and PYY promotes

${ }^{1}$ Pediatric Pulmonology, University of Michigan Health System, Ann Arbor, Michigan.

${ }^{2}$ Clinical Nutrition Department, Montreal Children's Hospital, McGill University Health Centre, Montreal, Canada.

*Correspondence to: Samya Z. Nasr, MD, Department of Pediatrics, University of Michigan Health System, 1500 E. Medical Center Dr., SPC 5212, Ann Arbor, MI 48109-5212. E-mail: snasr@med.umich.edu

Received 9 July 2007; Revised 5 November 2007; Accepted 12 November 2007.

DOI 10.1002/ppul.20766

Published online in Wiley InterScience

(www.interscience.wiley.com). 


\begin{tabular}{|c|c|c|c|}
\hline \multicolumn{2}{|c|}{ CF related } & \multicolumn{2}{|c|}{ Can occur in people with $\mathrm{CF}$} \\
\hline $\begin{array}{l}\text { Acute illness, pulmonary exacerbation, } \\
\text { inflammation, increased cytokines }\end{array}$ & $\begin{array}{l}\text { Poor gastric emptying and/or } \\
\text { gastroesphageal reflux }\end{array}$ & $\begin{array}{l}\text { Depression, anxiety, stress or } \\
\text { sadness }\end{array}$ & $\begin{array}{l}\text { Eating disorder or disordered } \\
\text { eating behaviors }\end{array}$ \\
\hline $\begin{array}{l}\text { DIOS (distal intestinal obstructive } \\
\text { syndrome) or constipation leading } \\
\text { to abdominal pain and nausea }\end{array}$ & $\begin{array}{l}\text { Nasal polyps which may } \\
\text { impair taste or the ability to } \\
\text { eat and breathe comfortably } \\
\text { at the same time }\end{array}$ & Inflammatory bowel disease & $\begin{array}{l}\text { Appetite neuro-transmitter } \\
\text { abnormality (ghrelin, peptide Y, } \\
\text { leptin, insulin) }\end{array}$ \\
\hline $\begin{array}{l}\text { Avoidance of foods mistakenly thought } \\
\text { to be 'bad' for CF ("carbohydrates } \\
\text { causing CF-related Diabetes", "fats } \\
\text { causing abdominal pain", "milk/milk } \\
\text { products causing secretions", etc.). }\end{array}$ & $\begin{array}{l}\text { Sinusitis which may be } \\
\text { associated with pain with } \\
\text { chewing, or altered taste }\end{array}$ & $\begin{array}{l}\text { Medications (some } \\
\text { antidepressants or attention } \\
\text { deficit hyperactivity } \\
\text { disorder (ADHD) } \\
\text { medications) }\end{array}$ & Economic oraccess issues \\
\hline \multicolumn{2}{|c|}{ Burden of therapies on time and energy to prepare and eat nutritious foods } & \multicolumn{2}{|c|}{ Abdominal pain, bloating or other symptoms of malabsorption } \\
\hline
\end{tabular}

satiety by inhibiting gut motility. Thirdly, there is the metabolic phase which results in the release of glucose, insulin, and leptin. Finally, the ileal phase results in the inhibition of gastric motility by inhibiting neuropeptide $\mathrm{Y}$ release from the brain. ${ }^{6-9}$

In order to understand malnutrition in $\mathrm{CF}$, each phase of this process must be considered. Diagnosing the cause of an individual's malnutrition requires careful, multidisciplinary history taking, physical exam, and overall patient/ family assessment. Only by determining the actual cause of the malnutrition can appropriate and safe therapies be used to treat it. Table 2 provides a framework for this process. Issues listed in the table should be addressed thoroughly. If malnutrition persists, appetite stimulants should be considered.

Appetite stimulants, although efficacious in treating malnutrition in $\mathrm{CF}$, should only be prescribed if decreased food intake secondary to inadequate appetite is the principal cause of the malnutrition and all other contributing factors have been assessed, ruled-out, or treated. For example, if depression is the principle cause of poor food intake in a person with $\mathrm{CF}$, it would be appropriate to consider consulting a psychologist or a psychiatrist. It is important that physicians treating depression in $\mathrm{CF}$ are aware of the secondary effects of different antidepressants on appetite in order not to further exacerbate the problem. If the only therapy provided is appetite stimulants, the problem of poor appetite may be effectively reversed, but the depression is still present and untreated. Similarly,

\begin{tabular}{|ll|}
\hline ABBREVIATIONS \\
CF & cystic fibrosis \\
MA & megestrol acetate \\
CH & cyproheptadine hydrochloride \\
BMI & body mass index \\
BWG & body weight gain \\
APDs & antipsychotic drugs \\
rhGH & recombinant human growth hormone \\
LBM & lean body mass \\
AAS & anabolic androgenic steroids \\
\hline
\end{tabular}

if poor GI motility is the primary cause of poor food intake, increased intakes achieved by the use of appetite stimulants may lead to the exacerbation of the GI symptoms. In this case, motility agents may be equally or more effective and the underlying problem, not just the symptoms, would be treated. Clinically, many of these issues may be inseparable and appetite stimulants may need to be prescribed in concert with other treatments, but the other issues should also receive the attention and treatment they deserve.

In this review, we attempted to summarize the use of several appetite stimulants used in CF patients and patients with other chronic diseases to improve their appetite and maximize their caloric intake.

\section{MEGESTROL ACETATE (MA)}

Megestrol acetate (MA) (Megace ${ }^{\circledR}$ ) is a synthetic, orally active derivative of progesterone. It is widely used in treating advanced breast cancer. ${ }^{10}$ One of the side effects of MA is appetite stimulation and weight gain. ${ }^{10}$ The mechanism of action has not been established. It has been postulated that the effect is partly mediated by neuropeptide Y, a potent central appetite stimulant. ${ }^{11}$ In animal models, MA stimulates its synthesis, transport, and release, which may contribute to its appetite-stimulating effect. ${ }^{12}$ Another speculation of its mechanism of action is that it is a potent inducer of adipocyte differentiation in 3T3-L1 cells in vitro, raising the possibility that it stimulates the conversion of fibroblasts to adipocytes, thereby blocking or reversing the effect of tumor necrosis factor on lipocyte differentiation. ${ }^{13,14}$ It has been used successfully as an appetite stimulant in adult patients with cancer and acquired immunodeficiency syndrome (AIDS). ${ }^{15-22}$ It also improved patients' general sense of well-being. ${ }^{19-21}$

MA has been used in CF to treat anorexia and weight loss. $^{23-25}$ In a case report, four patients, ages $10-$ 18.5 years, with severe CF lung disease, anorexia and weight loss received MA in an effort to stimulate their 
TABLE 2-Work-Up Strategies for Malnutrition in Cystic Fibrosis

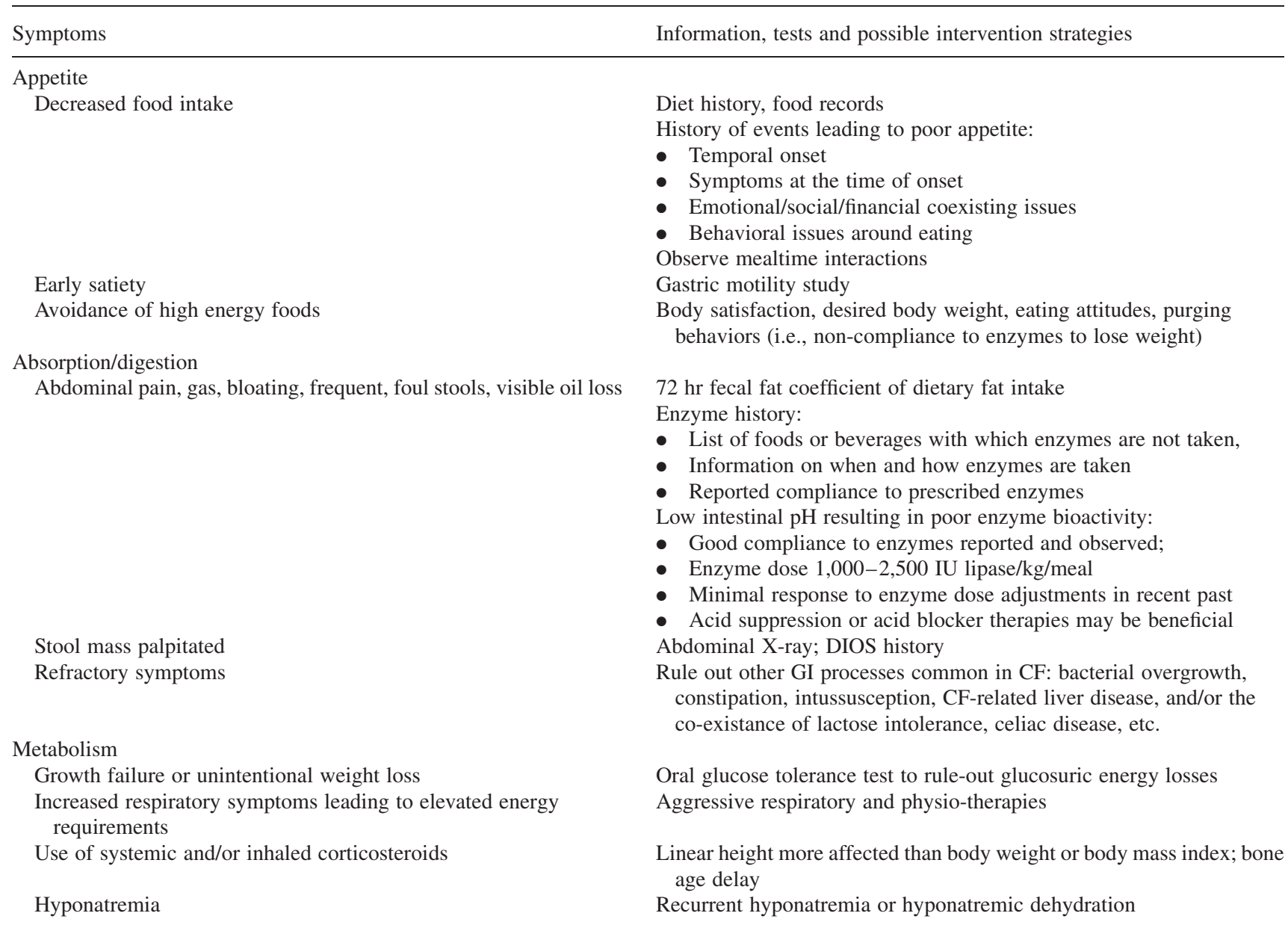

appetite and improve weight gain. Three of the four patients received gastrostomy tube feedings, and all were pancreatic insufficient. The dose was $400-800 \mathrm{mg}$ daily and duration of use was 6-15 months. Appetite improved, with significant weight gain in all patients and an increase in mean weight for age percentile from $<5$ th percentile to approximately 25 th percentile after 6 months of therapy was noted. Quality of life was also shown to improve. ${ }^{23}$ Side effects were not reported in this case report. A randomized, double-blind, placebo-controlled, crossover pilot trial of MA in 12 malnourished children with $\mathrm{CF}$ was conducted over a 12 -week period, followed by a 12 -week washout period, then the alternative treatment. ${ }^{24}$ The age range was 21 months to 10.4 years. Six patients didn't complete the study, three for reasons unrelated to the study, two because of developing diabetes while receiving $\mathrm{MA}$, and one who developed glucose intolerance while receiving the placebo. Weight $\mathrm{Z}$-score, body fat, and lean body mass (LBM) increased, and pulmonary function improved in patients given MA. There was little change in linear growth during MA therapy. Side effects included glucosuria, insomnia, hyperactivity, and irritability. ${ }^{24}$
Another randomized, double-blind, placebo-controlled study was conducted to evaluate the effects of MA on CF patients. ${ }^{25}$ Seventeen patients age 6 years and above were enrolled in the study. MA dose used was $7.5-15 \mathrm{mg} / \mathrm{kg} /$ day. The study duration was 6 months. The treatment group had significant increase in weight-for-age Z-score and reached $100 \%$ of their ideal body weight within 3 months of initiating therapy. Weight gain included both fat and fat-free mass as measured by dual energy X-ray absorptiometry (DXA). Pulmonary function improved in the treatment group compared to the placebo group. Reversible adrenal suppression was observed in the majority of patients who received MA. Some patients suffered from insomnia and moodiness while on MA. ${ }^{25}$ We observed adrenal suppression, diabetes and insomnia in patients treated with long term MA (unpublished data). MA was also reported to cause testicular failure in $\mathrm{CF}$ patients and impotence in HIV-infected patients, along with its known glucocorticoid-like activity sometimes leading to Cushing Syndrome and adrenal insufficiency. ${ }^{17,26,27}$ A case report of osteoporosis associated with MA use in cancer patients was also documented. ${ }^{28}$ 


\section{CYPROHEPTADINE HYDROCHLORIDE (CH)}

Cyproheptadine hydrochloride $(\mathrm{CH})$ (Periactin $\left.{ }^{\circledR}\right)$ is a first-generation antihistamine which is both a histamine and serotonin antagonist. It is also known to have a secondary effect of appetite stimulation. ${ }^{29,30}$ The mechanism of action is unknown but it is not due to hypoglycemic induced hyperphagia, as evidenced by normal glucose tolerance testing and normal insulin levels during use. In addition, it is not due to an increase in endogenous growth hormone $(\mathrm{GH}){ }^{29,30}$ It was found to stimulate weight gain in normal, underweight adults. ${ }^{31}$ $\mathrm{CH}$ was shown to be an effective appetite stimulant in two studies of asthmatic children. ${ }^{29,32}$ It was also shown to be an effective appetite stimulant in anorexia nervosa ${ }^{33}$ and tuberculosis. ${ }^{34}$ However, $\mathrm{CH}$ was not shown to be effective in producing weight gain in advanced cancer with cachexia. ${ }^{35-37}$ Both MA and $\mathrm{CH}$ were studied in HIV patients and were found to be beneficial. ${ }^{38}$

A 12-week, randomized, double-blind, controlled study of $\mathrm{CH}$ versus placebo was conducted in $18 \mathrm{CF}$ patients. ${ }^{39}$ The dose used was $4 \mathrm{mg}$ QID, and the duration of the study was 3 months. Sixteen patients completed the study. Subjects in the $\mathrm{CH}$ group showed significant increases in weight, height, body mass index (BMI) percentiles, ideal body weight/height, weight for age Z-scores, and fat and fat-free mass versus the placebo group. There were no differences in antibiotic use or spirometric measures between the two groups. No significant side effects, except transient mild sedation, occurred in the $\mathrm{CH}$ group and patients' acceptance and adherence were good. ${ }^{39} \mathrm{~A}$ follow-up study was conducted to evaluate the long-term use of $\mathrm{CH}^{40}$ Sixteen $\mathrm{CF}$ patients enrolled and $12 \mathrm{com}-$ pleted a 9-month open-label trial following the completion of the double-blind study. ${ }^{40}$ Subjects who had changed from placebo to $\mathrm{CH}$ gained weight significantly over 3-6 months, and those continuing on $\mathrm{CH}$ generally maintained previously gained weight over the duration of the study. There were some improvements, not statistically significant, in selected spirometric measures and side effects were mild. ${ }^{40}$ From these studies, $\mathrm{CH}$ seems to be safe and well-tolerated. It has a modest positive effect on weight in most subjects, and with most of the gain occurring in the first few months of use. ${ }^{39,40}$

\section{DRONABINOL (Marinol ${ }^{\circledR}$ )}

Dronabinol (Marinol ${ }^{\mathbb{R}}$ ) is an oral form of delta-9tetrahydrocannabinol dissolved in sesame oil in soft gelatin capsules. It is the principal psychoactive substance present in marijuana. It is utilized as an alternative to smoked marijuana for AIDS wasting syndrome and nausea following chemotherapy. ${ }^{41}$ An important gap in the knowledge base about dronabinol has been an accurate assessment of its abuse potential. ${ }^{41}$ The most common reasons for medicinal use of marijuana in HIV/AIDS are appetite stimulation, weight gain, sleep, relaxation, depression, nausea, vomiting, pain, and combating antiretroviral side effects. ${ }^{42,43} \mathrm{~A}$ number of studies cite the use of marijuana for treatment of cancer-related anorexia, nausea, vomiting, pain, and mood disorders. ${ }^{44,45}$ There is no evidence of abuse or diversion of dronabinol. There is no street market or value for dronabinol. ${ }^{41}$ Furthermore, it doesn't provide effects that are considered desirable in a drug of abuse. ${ }^{41}$ The onset of action is slow and gradual, its effects are dysphoric and unappealing. ${ }^{41,43}$

A long-term study (12 months) of dronabinol was conducted in 94 late-stage AIDS patients who previously participated in a 6-week double-blind placebo-controlled study. ${ }^{46}$ All patients received dronabinol orally at a dose of $2.5 \mathrm{mg}$ twice daily (90\%) or $2.5 \mathrm{mg}$ once daily (10\%). The long-term use of dronabinol resulted in consistent increase in appetite with trends toward weight stabilization and modest weight gain in AIDS patients. ${ }^{46,47}$ In addition, the data from this study suggested that it may be administered long-term in this patient population without development of tolerance to the therapeutic effect. Few patients developed adverse events which were related to the central nervous system, for example, anxiety, confusion, euphoria, and somnolence. ${ }^{47}$

It has been proposed to administer dronabinol to $\mathrm{CF}$ patients to alleviate malnutrition and help treat wasting, especially with severe disease. ${ }^{48}$ It was utilized in $11 \mathrm{CF}$ patients with severe nutritional deficiencies who had failed conventional interventions of nutritional counseling and high calorie supplement. The average age of the patients was 25.9 years (range 14-44 years), and the average weight at the start of the study was $96.6 \mathrm{lbs}$. Mean $\mathrm{FEV}_{1}$ was $26 \%$ of predicted. Patients were treated on average for 3 months (range 1-6 months). The starting dose was $2.5 \mathrm{mg}$ in all patients and maximum dose was $5 \mathrm{mg}$ twice daily. ${ }^{49}$ Patients receiving dronabinol had a significant improvement in weight during the treatment period $(P=0.03)$, with average weight at the end of the treatment period of $103.8 \mathrm{lbs} . \mathrm{FEV}_{1}$ was $26.5 \%$ of predicted, which was not statistically significant. Side effects noted during the study period were euphoria, hallucinations, and lethargy; each side effect only occurred in one patient. All side effects responded to lowering the dosage. No patients stopped the medication due to side effects. ${ }^{49}$

In conclusion, dronabinol is a safe and effective appetite stimulant with potential effectiveness in CF.

\section{ANTIPSYCHOTIC/ANTIDEPRESSANT AGENTS}

\section{Antipsychotic Drugs}

Excessive body weight gain (BWG) is a common side effect of some typical and atypical antipsychotic drugs 
(APDs).$^{50}$ Weight gain is linked to a decreased metabolic rate, increased caloric intake, and decreased physical activity. ${ }^{51}$ It is generally believed that there are multiple mechanisms by which APDs induce weight gain, but their precise nature remains unknown. Weight gain as a drug effect may be a multifactorial process, involving serotonergic, histaminergic, and/or adrenergic neurotransmission. ${ }^{51}$ A new generation of agents, the atypical APDs, represents an important progress in the treatment of psychotic disorders. Atypical antipsychotics achieve their therapeutic effects by modulating the activity of these neural pathways. Weight gain as a side effect may also be due to the blockade of certain receptors, for example, $5-\mathrm{HT}_{2 \mathrm{c}}$, that modulate appetite and body weight. ${ }^{52}$ Weight gain is dependent on the specific drug and individual patient. The atypical antipsychotics vary in their propensity to cause weight change with the long-term treatment. The largest weight gains are associated with clozapine and olanzapine, and the smallest with quetiapine and ziprasidone. Risperidone is associated with modest weight gain that is not dose related. ${ }^{53}$ However, clozapine and olanzapine appear to display a high propensity to induce glucose dysregulation and dyslipidemia. Insulin secretion is preserved and thus high serum insulin levels are observed; there appears to be peripheral insulin resistance, which leads to glucose intolerance and type 2 diabetes mellitus (DM).$^{50}$ Sudden BWG, insulin resistance, increased appetite, and related endocrine changes also may be involved in the development of glucose intolerance and dyslipidemia in predisposed individuals. Patients' blood glucose and lipids should be monitored before treatment and at regular intervals. ${ }^{50}$

The use of olanzapine in an 18-year-old female with $\mathrm{CF}$ and severe body dysmorphism led to a significant increase in body weight, possibly by stimulating appetite. ${ }^{54}$ This observation led to a larger open-label trial of low dose olanzapine therapy in a group of 12 adults with CF who had previously been losing weight despite maximal conventional therapy. ${ }^{54}$ Age range was $18-40$ years, with a mean age of 21 years. Mean $\mathrm{FEV}_{1}$ was $27.4 \%$ predicted. Eleven of the 12 subjects were pancreatic insufficient, and 7 subjects were on regular insulin therapy. Olanzapine was started at $5 \mathrm{mg}$ daily (usual range in psychiatric practice is $10-20 \mathrm{mg}$ daily). Ten subjects continued olanzapine for at least 6 months. In two subjects, biochemical evidence of liver dysfunction was detected shortly after starting therapy and led to discontinuation of treatment with subsequent normalization of liver function. Four subjects reported increased sleepiness which responded to adjustment of the time of dosing. Six subjects reported an increase in appetite. At baseline, mean (SD) BMI was $16.65( \pm 1.01)$. After 6 months, BMI was $18.61( \pm 2.01)$. When compared to baseline, change in BMI after 6 months of therapy was statistically significant $(P=0.01$, Wilcoxon sign-rank test). ${ }^{54}$

\section{Antidepressants}

Psychological functioning has been assessed in both children and adults with $\mathrm{CF}$, but the results have been variable. Some studies have reported relatively normal adjustment in older adolescent and adult $\mathrm{CF}$ patients. ${ }^{55-61}$ However, other studies have suggested elevated levels of psychosocial impairment, including anxiety, depression, and eating disorders. ${ }^{62-65}$ Most of the second group of studies were done earlier than the first group (in the 1960s until early 1990s). That might be a reflection of the poorer treatment options and the shortened life expectancy then. Overall, adults with CF report relatively healthy psychological functioning. ${ }^{55}$ Better lung function and a strong social support system predicted better psychological functioning. ${ }^{55}$ The prevalence of psychological and psychosocial dysfunction of people with CF is associated with worsening disease severity and lack of social support. ${ }^{55,66}$ Antidepressants have been used, in addition to other psychosocial interventions, to treat depression in CF patients. ${ }^{67}$

In addition, antidepressants have been used as appetite stimulants. All antidepressants have side-effects, including appetite dysregulation. The non-adrenergic and specific serotonergic antidepressants block the $5-\mathrm{HT}_{2 \mathrm{C}}$ receptor (one of the serotonin receptors). Blockage of this receptor may lead to an increase in appetite. ${ }^{68}$ They also block the $5-\mathrm{HT}_{3}$ (another serotonin receptor) which is the main site of action for nausea and occasional emesis. These two symptoms are usually associated with decreased appetite and failure to gain adequate weight in patients with severe CF disease. ${ }^{68}$

Mirtazapine (Remeron ${ }^{\mathbb{R}}$ ) is a noradrenergic and specific serotonergic antidepressant (NaSSA). It also has an antihistamine effect. Its tolerability and safety profile reflects a unique pharmacological profile. It is well tolerated and shows particular benefits over other antidepressants in terms of antianxiolytic effects, sleep improvement, and gastrointestinal side-effects. Its main side-effect is weight gain. $^{68}$

Mirtazapine has been used as an appetite stimulant in malnourished CF patients. ${ }^{69,70}$ The first study was a pilot study of five patients age 14-19 years with mean $\mathrm{FEV}_{1}$ of $41.4 \%$ with growth failure. They were started on $15 \mathrm{mg}$ of mirtazapine once a day. Patients were on the medication for a mean of 96 days (range 29-142 days). All subjects demonstrated an increase in weight $(5.8 \mathrm{~kg}, P<0.01)$, body fat $(13.9-21.8 \mathrm{~kg}, P<0.01)$ and an increase in weight gain velocity $(-3.9$ before starting treatment vs. $27.4 \mathrm{~kg} /$ year after treatment, $P<0.05)$. All subjects reported mild sedation, dry mouth, increased thirst and increased appetite. None of the subjects felt these symptoms justified stopping the medication. ${ }^{69}$ The second study was a retrospective study. Six patients were enrolled. Age range was 10-17 years at the start of 
therapy. Doses ranged from 15 to $45 \mathrm{mg}$ once daily. Patients received an average of 14.2 months of therapy (range 8-28 months). All patients had an increase in BMI percentile for age (mean $10.3 \%$, median $8 \%$, and range $2-$ $25 \%$ ). Adverse effects were limited to somnolence. ${ }^{70}$

\section{RECOMBINANT HUMAN GROWTH HORMONE (rhGH)}

Growth hormone (rhGH) has been approved by the Food and Drug Administration for use in treating AIDS-associated wasting. ${ }^{71} \mathrm{GH}$ is a potent anabolic agent that has been used in the posttraumatic state to reduce nitrogen loss. ${ }^{72}$ The nitrogen retention induced by GH is associated with increased whole-body protein synthesis and LBM as well. ${ }^{72}$ Human GH is a single polypeptide chain composed of 191 amino acids (molecular weight $22 \mathrm{KD}$ ) and coded on chromosome $17 .^{71}$ Secreted by the somatotrophs of the anterior pituitary gland, GH promotes protein synthesis and fat utilization and decreases glucose oxidation. ${ }^{71} \mathrm{GH}$ stimulates the production of insulin-like growth factor (IGF-I) in the liver and other organs (muscle, bone, adipose tissue). ${ }^{71}$

The recommended dosage of rhGH is $4-6 \mathrm{mg}$ administered by subcutaneous injection daily. It offers a more expensive alternative, approximately 10-15 times the cost, to appetite stimulants such as MA and dronabinol. ${ }^{71,73}$ The adverse effects associated with rhGH therapy include mild edema and arthralgias, carpal tunnel syndrome, gynecomastia, insulin resistance, and glucose intolerance. Nonetheless, treatment has generally been well tolerated. ${ }^{74,75}$ In children, using rhGH for long-term replacement can lead to irreversible adverse effects such as slipped capital femoral epiphysis, acromegaly, and leukemia. $^{71}$

Previous studies have documented that patients with $\mathrm{CF}$ have a delay in attainment of pubertal maturation. ${ }^{76}$ The relationship between weight gain and linear growth was done, and a poor correlation was found between the two. ${ }^{77}$ This study concluded that nutritional supplementation alone may not be the best means for improving short stature in $\mathrm{CF} .{ }^{77} \mathrm{GH}$ stimulates accrual of linear height and has been used to improve weight gain in chronic illness. $^{78,79}$

Several studies have documented the safety and efficacy of $\mathrm{GH}$ in improving growth and clinical status in $\mathrm{CF}$ patients. ${ }^{80-85}$ A 1 year randomized controlled trial to test the effect of GH on the clinical status of CF children was conducted. ${ }^{80}$ Nineteen prepubertal children were recruited. The GH treatment group had significantly greater height, height velocity, weight, weight velocity, and change in lean tissue mass. There was also significant improvement in delta forced vital capacity (FVC) compared with the year before the study; respiratory muscle strength also improved. The number of hospitalizations and outpatient intravenous antibiotic courses significantly decreased. ${ }^{80}$ A multicenter, randomized, controlled trial that included 61 prepubertal CF patients confirmed the results of this study. The study duration was 1 year. ${ }^{81}$

Another study evaluated the mechanism of the anabolic effect of rhGH in $\mathrm{CF}$ patients. It was also evaluated whether glutamine (GLN) (which has shown improvement of nitrogen balance in diseases associated with severe stress and protein wasting when supplemented orally) alone has a protein anabolic effect. It also evaluated if the combination of GLN and rhGH is more potent than either one alone. ${ }^{82}$ Nine undernourished or short CF children were recruited. The study concluded that in children with CF (1) oral GLN may not promote protein gain in the fasting state; and (2) a short course of rhGH has a potent anabolic effect that is mediated by stimulation of protein synthesis and does not affect GLN kinetics. ${ }^{82}$

GH was reported to enhance nutrition and growth in $\mathrm{CF}$ children receiving enteral nutrition. ${ }^{83}$ A retrospective study of GH use in pubertal CF adolescents suggested that GH safely improved height, body weight, bone mineralization, and clinical status. ${ }^{84} \mathrm{GH}$ was evaluated in eight adult $\mathrm{CF}$ patients with mild or moderate pulmonary disease. In this study, GH appears to improve weight and body composition. ${ }^{85}$ In patients with severe pulmonary disease, GH appears to stabilize loss of weight, bone and muscle mass. ${ }^{85}$

A multicenter, randomized, double-blind, placebocontrolled trial was conducted to evaluate the metabolic and respiratory effects of $\mathrm{GH}$ in $63 \mathrm{CF}$ children (bone age $8-18$ years). ${ }^{86} \mathrm{BMI}$ was $<10$ and/or weight $<3$ percentile despite a high caloric intake ( $>120 \%$ RDA). Height and growth velocity as well as growth factors (IGF1, IGFBP3) increased significantly $(P<0.05)$. A significant effect on weight gain was not observed. $\mathrm{FEV}_{1}$ both absolute and in percent predicted didn't change significantly with GH treatment. The study concluded that GH therapy had positive metabolic effects but didn't improve lung function in $\mathrm{CF}$ patients. ${ }^{86}$

\section{ANABOLIC ANDROGENIC STEROIDS (AAS)}

Since anabolic androgenic steroids (AAS) are derivatives or structural modifications of the parent steroid hormone, testosterone, they exhibit both anabolic and androgenic activities. ${ }^{87}$ Anabolic effects are the promotion of protein synthesis, nitrogen retention, and skeletal muscle growth. Androgenic effects are the development and maintenance of primary and secondary sexual characteristics in males. In females, androgenic effects are evident as male pattern baldness, deepened voice, clitoromegaly, and growth of facial hair. ${ }^{87}$ Oxandrolone has marked anabolic activity and few androgenic effects (ratio 10:1), in comparison with testosterone and methyl- 
testosterone. ${ }^{88}$ It is a marked contrast with other oral AAS that are metabolized extensively in the liver, oxandrolone is relatively resistant to liver biotransformation. Approximately $28 \%$ of it is excreted unchanged and unconjugated in the urine. ${ }^{89}$ Oxandrolone is the only AAS that is US FDA approved for restitution of weight loss after severe trauma, extensive surgery, chronic infections, malnutrition due to alcoholic cirrhosis, and Duchenne's or Becker's muscular dystrophy. ${ }^{87}$ Statistically significant improvements were reported in the areas of body composition, recovery, muscle strength, and function, and/or functional status. ${ }^{87}$ Oxandrolone is used in the treatment of short stature due to Turner's syndrome and constitutional delay of growth and puberty. ${ }^{90,91}$ It is used in acute catabolic disorders (e.g., burn injury and acute multiple trauma). ${ }^{87}$ It is also used in chronic catabolic disorders, for example, moderate to severe alcoholic hepatitis, chronic obstructive pulmonary disease (COPD), and Crohn's disease. ${ }^{87}$ It has been used also in wasting associated with HIV/AIDS. ${ }^{87}$ Adverse effects include hepatic dysfunction (increased transaminase levels), androgenic effects (alopecia, hirsutism, deep voice, and clitoromegaly in girls and women). ${ }^{87}$ It has not been studied in CF patients.

Prednisone has been studied in CF patients with mildmoderate pulmonary disease to assess its effect on the pulmonary inflammatory process. ${ }^{92}$ The study was a 4year, double-blind, placebo-controlled trial of alternateday prednisone $(2 \mathrm{mg} / \mathrm{kg})$ in $45 \mathrm{CF}$ patients. The patients in the prednisone group showed better growth and pulmonary function and less morbidity compared with those in the placebo group. No complications were reported. Because of this observation, the United States Cystic Fibrosis Foundation sponsored a multicenter, double-blind, placebo-controlled trial of alternate-day prednisone at a dose of $2 \mathrm{mg} / \mathrm{kg}$ (high dose), $1 \mathrm{mg} / \mathrm{kg}$ (lowdose), or placebo every other day for 4 years. Two hundred eighty five patients from $15 \mathrm{CF}$ centers were enrolled in the study from 1986 to 1987 . An interim safety analysis was done with mean duration in the study of 33.9 months for the high-dose, 35.3 months for the low-dose, and 36.8 months for the placebo groups. ${ }^{93}$ This analysis revealed increased frequency of cataracts, growth retardation, and glucose abnormalities among patients in the high-dose group.

In view of these results, it was recommended by the study ombudsman and a special advisory panel that the study drug be discontinued for all patients in the highdose prednisone group. ${ }^{93}$ At the end of the study, there was significant improvement in the $1 \mathrm{mg}$ group compared to placebo in FVC $(P<0.025)$ in patients colonized with Pseudomonas aeruginosa at baseline. ${ }^{94}$ In addition, there was significant improvement in predicted forced expiratory volume in $1 \mathrm{sec}\left(\mathrm{FEV}_{1}\right)$ in the $1 \mathrm{mg} / \mathrm{kg}$ group compared to placebo $(P<0.02)$ and reduction in serum
IgG concentrations ( $1 \mathrm{mg} / \mathrm{kg}$ vs. placebo, $P<0.007 ; 2 \mathrm{mg} /$ $\mathrm{kg}$ vs. placebo, $P<0.003)$. From 6 months onward, height Z-scores fell in the $2 \mathrm{mg} / \mathrm{kg}$ group compared to placebo $(P<0.001)$. For the $1 \mathrm{mg} / \mathrm{kg}$ group, height $\mathrm{Z}$-scores were lower at 24 months. An excess of abnormalities in glucose metabolism was seen in the $2 \mathrm{mg} / \mathrm{kg}$ group compared with the placebo group $(P<0.005))^{94}$

An evaluation of growth pattern, 6-7 years after prednisone was discontinued in the previous study was done retrospectively, through data collected from the $\mathrm{CF}$ Foundation Patient Registry. The findings indicate that growth suppression induced by long-term alternate-day prednisone therapy was long-lasting in male children with CF. The impact was particularly pronounced when prednisone was taken prior to adolescence, in which case final adult height appeared to be affected. ${ }^{95}$

Even though oxandrolone seems to be effective in treating wasting and catabolic disorders in different chronic disorders, long-term use of prednisone had the opposite effect on growth in $\mathrm{CF}$.

\section{DISCUSSION}

In view of the burden and demands on $\mathrm{CF}$ patient to achieve normal growth and development, appetite stimulants could be offered to help increase caloric intake. A list of appetite stimulants discussed in this review is summarized in Table 3. Several factors can lead to poor appetite and food intake in CF patients. Some of these factors are directly related to $\mathrm{CF}$ and others may be more prevalent in CF. Appetite stimulants should be used only after all other causes of weight loss and growth failure have been excluded. They should be limited to patients in whom conventional measures fail. Choice of appetite stimulants should be made according to physician, and CF care team experience, patient's age, severity of CF disease and known side effects. In addition, the choice of appetite stimulant should be discussed with the patient/family prior to starting treatment. Side effects of the appetite stimulant of choice should be monitored closely. An algorithm of work up and intervention for $\mathrm{CF}$ patients at nutritional risk is summarized in Table 4.

It has been documented that $\mathrm{CF}$ patients have demonstrated an overall protein catabolism, even in non-acutely ill subjects. ${ }^{96-98}$ Negative protein balance may contribute to increased morbidity and mortality in CF by decreasing body mass, and possibly by worsening immune function. ${ }^{99}$ An earlier study illustrated that reversal of protein catabolism resulted in stabilization of pulmonary function and decreased hospitalization rate. ${ }^{100}$ Chronic inflammation and protein catabolism are linked to high levels of cytokines, particularly TNF- $\alpha$ in CF patients. ${ }^{98,101,102}$ In one study of $\mathrm{GH}$ treatment of malnourished $\mathrm{CF}$ subjects concluded that treatment with this agent resulted in marked decrease in TNF- $\alpha$ levels. ${ }^{98}$ The authors speculated that 
TABLE 3-Summary of Appetite Stimulants in CF

\begin{tabular}{|c|c|c|}
\hline Drug & Dosage & Side effects \\
\hline Megestrol acetate (MA) & $400-800 \mathrm{mg} /$ day or $7.5-15 \mathrm{mg} / \mathrm{kg} /$ day orally & $\begin{array}{l}\text { Glucosuria, insomnia hyperactivity, irritability, } \\
\text { reversible adrenal suppression }\end{array}$ \\
\hline Cyproheptadine hydrochloride $(\mathrm{CH})$ & $4 \mathrm{mg}$ BID-QID or $0.5 \mathrm{mg} / \mathrm{kg} /$ day orally & Transient mild sedation \\
\hline Dronabinal (Marinol ${ }^{\mathbb{R}}$ ) & $2.5 \mathrm{mg} \mathrm{qd}-5 \mathrm{mg}$ BID orally & Anxiety, confusion, euphoria, somnolence \\
\hline \multicolumn{3}{|l|}{ Antipsychotic } \\
\hline Olanzapine & $5-20 \mathrm{mg}$ qd orally & Liver dysfunction, sleepiness, hyperglycemia \\
\hline Risperidone & $0.5-5 \mathrm{mg} \mathrm{qd}$ orally & Glucose dysregulation, dyslipidemia \\
\hline \multicolumn{3}{|l|}{ Antidepressents } \\
\hline Mirtazapine $\left(\right.$ Remeron $\left.{ }^{\mathbb{R}}\right)$ & $15-45 \mathrm{mg}$ qd orally & Mild sedation, dry mouth, somnolence \\
\hline $\begin{array}{l}\text { Recombinant human growth hormone } \\
(\mathrm{rhGH})\end{array}$ & $4-6 \mathrm{mg}$ qd SC injection & $\begin{array}{l}\text { Mild edema, arthralgia, carpal tunnel syndrome, } \\
\text { gynecomastia, insulin resistance, glucose } \\
\text { intolerance. In children, slipped capital femoral } \\
\text { epiphysis, acromegaly, leukemia }\end{array}$ \\
\hline \multicolumn{3}{|l|}{ Anabolic androgenic steroids (AAS) } \\
\hline Oxandrolone & $0.1 \mathrm{mg} / \mathrm{kg} /$ day BID, orally & $\begin{array}{l}\text { Hepatic dysfunction, androgenic effects in } \\
\text { females (alopecia, hirsutism, deep voice, } \\
\text { clitoromegaly), development of primary } \\
\text { and secondary sexual features in males. Not } \\
\text { studied in CF }\end{array}$ \\
\hline
\end{tabular}

this may have been due to improved clinical status in this treated group.

Appetite stimulants can be used prior to resorting to invasive means to treat $\mathrm{CF}$ patients at nutritional risk. However, the use of appetite stimulants and their benefits in $\mathrm{CF}$ have been based on case reports and small studies. More research is needed in this area to establish the effect of improving nutritional status especially by adding appetite stimulants, on the proinflammatory markers (cytokines, TNF- $\alpha$ and others) and CF lung disease.

TABLE 4-Algorithm for Cystic Fibrosis Patients at Nutritional Risk (BMI Percentile $\leq \mathbf{2 5 \%}$ or Poor Weight Gain for 3 Months)

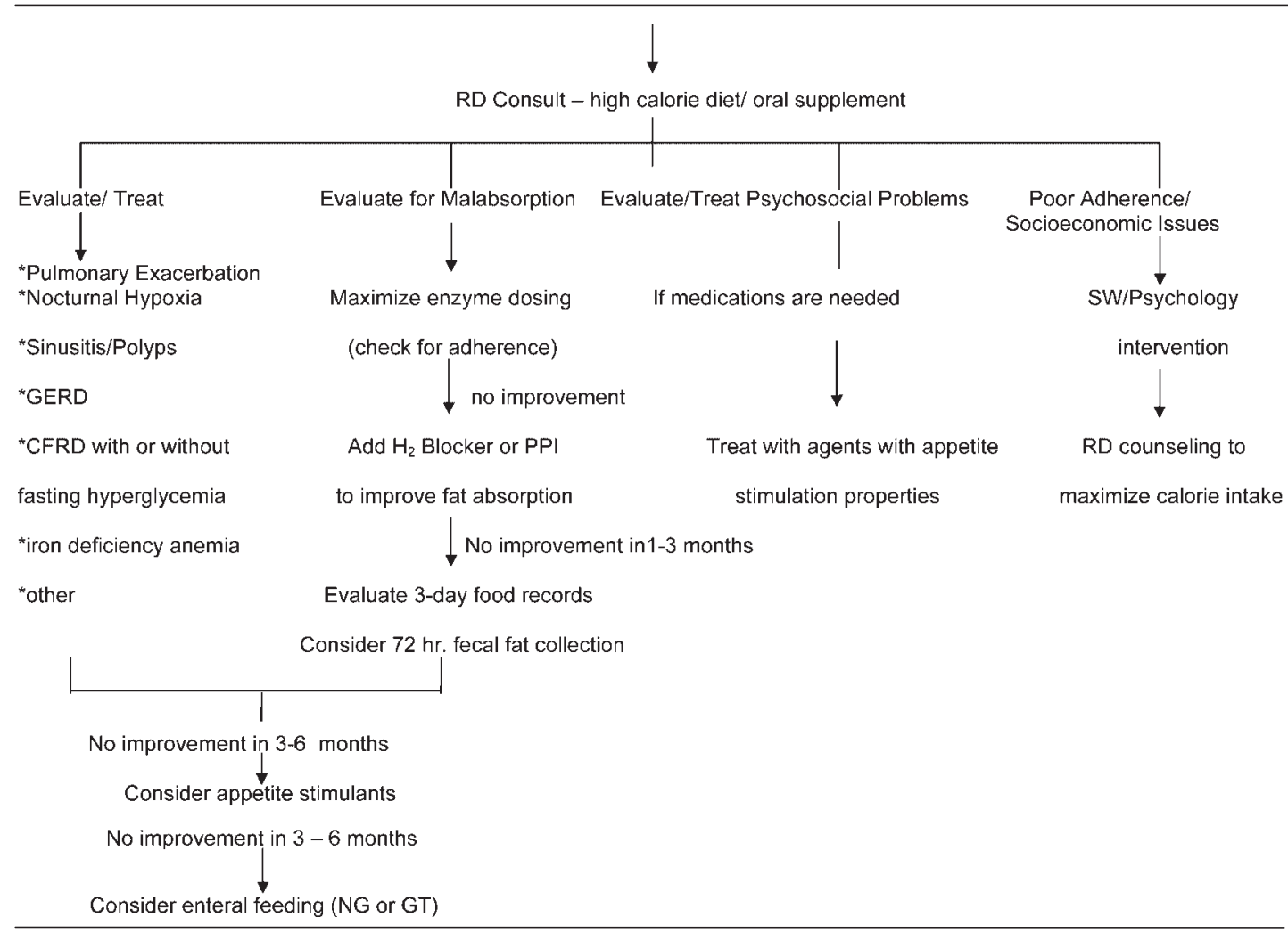


MA, CH, Dronabinol, and antidepressants have immunomodulatory effects. It would be interesting to study the effects of these agents on the inflammatory markers as well as appetite stimulation in large long terms studies. Larger comparative studies with different appetite stimulants in CF especially of longer durations and appropriately powered would be beneficial.

\section{REFERENCES}

1. Peterson ML, Jacobs DR, Milla CE. Longitudinal changes in growth parameters are correlated with changes in pulmonary function in children with cystic fibrosis. Pediatrics 2003;112: 588-592.

2. Konstan MW, Butler SM, Wohl ME, Stoddard M, Matousek R, Wagener JS, Johnson CA, Morgan WJ. Growth and nutritional indexes in early life predict pulmonary function in cystic fibrosis. J Pediatr 2003;142: 624-630.

3. Hart N, Tounian P, Clément A, Boulé M, Polkey MI, Lofaso F, Fauroux B. Nutritional status is an important predictor of diaphragm strength in young patients with cystic fibrosis. Am J Clin Nutr 2004;80:1201-1206.

4. Sharma R, Florea VG, Bolger AP, Doehner W, Florea ND, Coats AJ, Hodson ME, Anker SD, Henein MY. Wasting as an independent predictor of mortality in patients with cystic fibrosis. Thorax 2001;56:746-750.

5. Cystic Fibrosis Foundation. Cystic Fibrosis Foundation, patient registry 2003. Bethesda, MD: Cystic Fibrosis Foundation; 2004.

6. Druce M, Bloom SR. The regulation of appetite. Arch Dis Child 2006;91:183-187.

7. Small CJ, Bloom SR. Gut hormones and the control of appetite. Trends Endocrinol Metab 2004;15:259-263.

8. Blundell JE, Lawton CL, Cotton JR, Macdiarmid JI. Control of human appetite: implications for the intake of dietary fat. Ann Rev Nutrition 1996;16:285-319.

9. Misra M, Miller KK, Almazan C, Ramaswamy K, Aggarwal A, Herzog DB, Neubauer G, Breu J, Klibanski A. Hormonal and body composition predictors of soluble leptin receptor, leptin, and free leptin index in adolescent girls with anorexia nervosa and controls and relation to insulin sensitivity. J Clin Endocrinol Metab 2004;89:3486-3495.

10. Alexieva-Figusch J, van Gilse HA, Hop WCJ. Progestin therapy in advanced breast cancer. Megestrol acetate - an evaluation of 160 treated cases. Cancer 1980;46:2369-2372.

11. Strang P. The effect of megestrol acetate on anorexia, weight loss and cachexia in cancer and AIDS patients. Anticanc Res 1997; 17:657-662.

12. McCarthy H, Crowder R, Dryden S, Williams G. Megestrol acetate stimulates food and water intake in the rat: effects on regional hypothalamic neuropeptide $\mathrm{Y}$ concentrations. Eur J Pharmacol 1994;265:99-102.

13. Aisner J, Parnes H, Tait N, Hickman M, Forrest A, Greco FA, Tchekmedyian NS. Appetite stimulation and weight gain with megestrol acetate. Semin Oncol 1990;17:2-7.

14. Loprinzi CL, Johnson PA, Jensen M. Megestrol acetate for anorexia and cachexia. Oncology 1992;49:46-49.

15. Tchekmedyian NS, Hickman M, Heber D. Treatment of anorexia and weight loss with megestrol acetate in patients with cancer or acquired immunodeficiency syndrome. Semin Oncol 1991;18: $35-42$.

16. Feliu J, Gonzelez-Baron M, Berrocal A. Usefulness of megestrol acetate in cancer cachexia and anorexia: a placebo-controlled study. Am J Clin Oncol 1992;15:436-440.
17. Loprinzi CL, Ellison NM, Schaid DJ, Krook JE, Athmann LM, Dose AM, Mailliard JA, Johnson PS, Ebbert LP, Geeraerts LH. Controlled trial of megestrol acetate for the treatment of cancer anorexia and cachexia. J Nat Canc Inst 1990; 82:1127-1132.

18. Gebbia V, Testa A, Gebbia N. Prospective randomized trial of two dose levels of megestrol acetate in the management of anorexia-cachexia syndrome in patients with metastatic cancer. Br J Canc 1996;73:1576-1580.

19. Oster MH, Enders SR, Samuels SJ, Cone LA, Hooton TM, Browder HP, Flynn NM. Megestrol acetate in patients with AIDS and cachexia. Ann Intern Med 1994;121:400-408.

20. Von Roenn JH, Armstrong D, Kotler DP, Cohn DL, Klimas NG, Tchekmedyian NS, Cone L, Brennan PJ, Weitzman SA. Megestrol acetate in patients with AIDS-related cachexia. Ann Intern Med 1994;121:393-399.

21. Westman G, Bergman B, Albertsson M, Kadar L, Gustavsson G, Thanning L, Andersson M, Straumits A, Jeppson B, Lindén CJ, Ewers SB, Andersson H, Mercke C, Hafström L, Birck O, Orgum P. Megestrol acetate in advanced progressive hormoneinsensitive cancer. Effects on the quality of life: a placebocontrolled, randomised multicentre trial. Eur J Cancer 1999;35:586-595.

22. Tomiska M, Tomiskova M, Salajka F, Adam Z, Vorlicek J. Palliative treatment of cancer anorexia with oral suspension of megestrol acetate. Neoplasma 2003;50:227-233.

23. Nasr SZ, Hurwitz ME, Brown RW, Elghoroury M, Rosen D. Treatment of anorexia and weight loss with megestrol acetate in patients with cystic fibrosis. Pediatr Pulmonol 1999;28:380 382.

24. Marchand V, Baker SS, Stark TJ, Baker RD. Randomized, double-blind, placebo-controlled pilot trial of megestrol acetate in malnourished children with cystic fibrosis. J Pediatr Gastroenterol Nutr 2000;31:264-269.

25. Eubanks V, Koppersmith N, Wooldridge N, Clancy JP, Lyrene R, Arani RB, Lee J, Moldawer L, Atchison J, Sorscher EJ, Makris CM. Effects of megestrol acetate on weight gain, body composition, and pulmonary function in patients with cystic fibrosis. J Pediatr 2002;140:439-444.

26. Kawachak DA, Zhao H, Scanlin TF, Tomezsko JL, Cnaan A, Stallings VA. Longitudinal, prospective analysis of dietary intake in children with cystic fibrosis. J Pediatr 1996;129:119129.

27. Schmoll E, Wilke H, Thole R, Preusser P, Wildfang I, Schmoll HJ. Megestrol acetate in cancer cachexia. Semin Oncol 1991;18:32-34.

28. Wermers RA, Hurley DL, Kearns AE. Osteoporosis associated with megesterol acetate. Mayo Clin Proc 2004;79:1557-1561.

29. Bergen SS. Appetite stimulating properties of cyproheptadine. Am J Dis Child 1964;108:270-273.

30. Steil JN, Liddle GW, Lacy WW. Studies of mechanism of cyproheptadine-induced weight gain in human subjects. Metabolism 1970;19:192-200.

31. Noble RE. Effect of cyproheptadine on appetite and weight gain in adults. JAMA 1999;209:2054-2056.

32. Lavenstein AF, Dacaney EP, Lasagna L, Van Metre TE. Effect of cyproheptadine on asthmatic children. JAMA 1962;180:912916.

33. Goldberg SC, Halmi KA, Eckert ED, Casper RC, Davis JM. Cyproheptadine in anorexia nervosa. Br J Psychiatry 1979;134: $67-70$.

34. Rahman KM. Appetite stimulation and weight gain with cyproheptadine (Periactin) in tuberculosis patients (double-blind clinical study). Med J Malaysia 1975;29:270-274.

35. Loprinzi CL. Management of cancer anorexia/cachexia. Support Care Cancer 1995:3:120-122. 
36. Kardinal CG, Loprinzi CL, Schaid DJ, Hass AC, Dose AM, Athmann LM, Mailliard JA, McCormack GW, Grestner JB, Schary MF. A controlled trial of cyproheptadine in cancer patients with anorexia and/or cachexia. Cancer 1990;65: 26572662.

37. Tisdale MJ. Cancer anorexia and cachexia. Nutrition 2001;17: $438-442$.

38. Summerbell CD, Youle M, McDonald V, Catalan J, Gazzard BG. Megestrol acetate vs cyproheptadine in the treatment of weight loss associated with HIV infection. Int J STD AIDS 1992;3:278280.

39. Homnick DN, Homnick BD, Reeves AJ, Marks JH, Pimentel RS, Bonnema SK. Cyproheptadine is an effective appetite stimulant in cystic fibrosis. Pediatr Pulmonol 2004;38:129_ 134.

40. Homnick DN, Marks JH, Hare KL, Bonnema SK. Long-term trial of cyproheptadine as an appetite stimulant in cystic fibrosis. Pediatr Pulmonol 2005;40:251-256.

41. Calhoun SR, Galloway GP, Smith DE. Abuse potential of dronabinol (marinol ${ }^{\mathbb{R}}$ ). J Psychoactive Drugs 1998;30:187195.

42. Ware M, Rueda S, Singer J, Kilby D. Cannabis use by persons living with HIV/AIDS: patterns and prevalence of use. J Cannabis Ther 2003;3:3-15.

43. Braitstein P, Kendall T, Chan K, Wood E, Montaner JSG, O'Shaughnessy M, Hogg RS. Mary-Jane and her patients: sociodemographic and clinical characteristics of HIV-positive individuals using medicinal marijuana and antiretroviral agents. AIDS 2001;15:532-533.

44. Guzman M. Cannabinoids: potential anticancer agents. Nat Rev Cancer 2003;3:745-755.

45. Robson P. Therapeutic aspects of cannabis and cannabinoids. Br J Psychiatry 2001;178:107-115.

46. Beal JE, Olson R, Laubenstein L, Morales JO, Bellman P, Yangco B, Lefkowitz L, Plasse TF, Shepard KV. Dronabinol as a treatment for anorexia associated with weight loss in patients with AIDS. J Pain Symptom Manage 1995;10:89-97.

47. Beal JE, Olson R, Lefkowitz L, Laubenstein L, Bellman P, Yangco B, Morales JO, Murphy R, Powderly W, Plasse TF, Mosdell KW, Shepard KV. Long-term efficacy and safety of dronabinol for acquired immunodeficiency syndrome-associated anorexia. J Pain Symptom Manage 1997;14:7-14.

48. Fride E. Cannabinoids and cystic fibrosis; a novel approach to etiology and therapy. J Cannabis Ther 2002;2:59-71.

49. Anstead MI, Kuhn RJ, Martyn D, Craigmyle L, Kanga JF. Dronabinol, an effective and safe appetite stimulant in cystic fibrosis. Pediatr Pulmonol 2003;36:343.

50. Baptista T, Kin NMKNY, Beaulieu S, de Baptista EA. Obesity and related metabolic abnormalities during antipsychotic drug administration: mechanisms, management and research perspectives. Pharmacopsychiatry 2002;35:205-219.

51. Baptista T. Body weight gain induced by antipsychotic drugs: mechanisms and management. Acta Psychiatr Scand 1999;100: 3-16.

52. Stanton JM. Weight gain associated with neuoleptic medication: a review. Schizophr Bull 1995;21:463-472.

53. Nasrallah $\mathrm{H}$. A review of the effect of atypical antipsychotics on weight. Psychoneuroendocrinology 2003;28:83-96.

54. Ross E, Davidson S, Sriram S, Hempsey S, Jane Y, Margaret K, Bicknell S. Weight gain associated with low dose olanzapine therapy in severely underweight adults with cystic fibrosis. Pediatr Pulmonol 2005;40:350.

55. Anderson DL, Flume PA, Hardy KK. Psychological functioning of adults with cystic fibrosis. Chest 2001;119:10791084.
56. Cowen L, Corey M, Simmons R, Keenan N, Robertson J, Levison H. Growing older with cystic fibrosis: psychologic adjustment of patients more than 16 years old. Psychosom Med 1984:46:363-376.

57. Strauss D, Wellisch D. Psychological assessment of adults with cystic fibrosis. Int J Psychiatry Med 1980;10:265-272.

58. Shepherd SL, Hovell MF, Harwood IR, Granger LE, Hofstetter CR, Molgaard C, Kaplan RM. A comparative study of the psychosocial assets of adults with cystic fibrosis and their healthy peers. Chest 1990;97:1310-1316.

59. Mosie JR, Drotar D, Doershuk CF, Stern RC. Correlates of psychological adjustment among young adults with cystic fibrosis. J Dev Behav Pediartr 1987;8:141-148.

60. Cappelli M, McGrath PJ, Heick CE, MacDonald NE, Feldman W, Rowe P. Chronic disease and its impact. The adolescent's perspective. J Adolesc Health Care 1989;10:283288.

61. Blair C, Cull A, Freeman C. Psychosocial functioning of young adults with cystic fibrosis and their families. Thorax 1994; 49:798-802.

62. Boyle IR, di Sant'Angese PA, Sack S, Millican F, Kulcycki LL. Emotional adjustment of adolescents and young adults with cystic fibrosis. J Pediatr 1976;88:318-326.

63. Lawler R, Nakielny W, Wright N. Psychological implications of cystic fibrosis. Can Med Assoc J 1966;94:1043-1046.

64. Pearson D, Pumariega A, Seilheimer D. The development of psychiatric sumptomolgy in patients with cystic fibrosis. J Am Acad Child Adolesc Psychiatry 1991;30:290-297.

65. Pumariega AJ, Pursell J, Spock A, Jones JD. Eating disorders in adolescents with cystic fibrosis. J Am Acad Child Psychiatry 1986;25:269-275.

66. Pfeffer PE, Pfeffer JM, Hodson ME. They psychosocial and psychiatric side of cystic fibrosis in adolescents and adults. J Cyst Fibros 2003;2:61-68.

67. Elgudin L, Kishan S, Howe D. Depression in children and adolescents with cystic fibrosis: case studies. Int J Psychiatry Med 2004;34:391-397.

68. Nutt DJ. Tolerability and safety aspects of mirtazapine. Hum Psychopharmacol Clin Exp 2002;17:S37-S41.

69. Boas SR, McColley SA, Danduran MJ, Young J. The role of mirtazapine as an appetite stimulant in malnourished individuals with CF. Ped Pulmonol 2000;30:325.

70. Sykes R, Kittel F, Marcus M, Tarter E, Schroth M. Mirtazapine for appetite stimulation in children with cystic fibrosis. Ped Pulmonol 2006;40:389.

71. Windisch PA, Papatheofanis FJ, Matuszewski KA. Recombinant human growth hormone for AIDS-associated wasting. Ann Pharmacother 1998;32:437-445.

72. Jian Z-M, He G-Z, Zhang S-Y, Wang X-R, Yang N-F, Zhu Y, Wilmore DW. Low-dose growth hormone and hypocaloric nutrition attenuate the protein-catabolic response after major operation. Ann Surg 1989;210:513-525.

73. Medical Economics Company, Inc. Drug topics red book. Montvale, NJ: Medical Economics Company, Inc.; 1998.

74. Seronon Laboratories, Inc. Product information. Serostim (somatropin). Norwell, MA: Seronon Laboratories, Inc.; 1996.

75. Marcus R, Butterfield G, Holloway L, Gilliland L, Baylink DJ, Hintz RL, Sherman BM. Effects on short term administration of recombinant human growth hormone to elderly people. J Clin Endocrinol Metab 1990;70:519-527.

76. Byrand P. The adolescent growth spurt in children with cystic fibrosis. Ann Human Biol 1994;21:229-240.

77. Hardin DS. Growth problems and growth hormone treatment in children with cystic fibrosis. J Pediatr Endocrinol Metabolism 2002; $15: 731-735$. 
78. Bechtold S, Ripperger D, Muhlbayer H, Truckenbrodt R, Hafner $\mathrm{O}$, Butenandt O, Schwarz HP. GH therapy in juvenile chronic arthritis: results of a two-year controlled study on growth and bone. J Clin Endocrinol Metab 2002;86:5737-5744.

79. Koch VH, Lippe BM, Sherman BM, Fine RN. Accelerated growth following recombinant human growth hormone therapy in children with chronic renal failure. Pediatr Res 1988;23: 541A.

80. Hardin DS, Ellis KJ, Dyson M, Rice J, McConnell R, Seilheimer DK. Growth hormone improves clinical status in prepubertal children with cystic fibrosis: results of a randomized controlled trial. J Pediatr 2001;139:636-642.

81. Hardin DS, Adams-Huet B, Brown D, Chatfield B, Dyson M, Ferkol T, Howenstine M, Prestidge C, Royce F, Rice J, Seilheimer DK, Steelman J, Shepherds R. Growth hormone treatment improves growth and clinical status in prepubertal children with cystic fibrosis: results of a multicenter randomized controlled trial. J Clin Endocrinol Metab 2006;91:49254929.

82. Darmaun D, Hayes V, Schaeffer D, Welch S, Mauras N. Effects of glutamine and recombinant human growth hormone on protein metabolism in prepubertal children with cystic fibrosis. J Clin Endocrinol Metab 2004;89:1146-1152.

83. Hardin DS, Rice J, Ahn C, Ferkol T, Howenstine M, Spears S, Prestidge C, Seilheimer DK, Shepherd R. Growth hormone treatment enhances nutrition and growth in children with cystic fibrosis receiving enteral nutrition. J Pediatr 2005;146:324-328.

84. Hardin DS, Ferkol T, Ahn C, Dreimane D, Dyson M, Morse M, Prestidge C, Rice J, Seilheimer DK. A retrospective study of growth hormone used in adolescents with cystic fibrosis. Clin Endocrinol 2005;62:560-566.

85. Hardin DS, Rice J, Rosenblatt R. Use of growth hormone in adults with CF. Pediatr Pulmonol 2004;38:343.

86. Schnabel D, Grasemann C, Staab D, Wollmann H, Ratjen F. A multicenter, randomized, double-blind, placebo-controlled trial to evaluate the metabolic and respiratory effects of growth hormone in children with cystic fibrosis. Pediatrics 2007; e1230-e1238.

87. Orr R, Singh MF. The anabolic androgenic steroid oxandrolone in the treatment of wasting and catabolic disorders. Drugs 2004;64:725-750.

88. Kuhn CM. Anabolic steroids. Recent Prog Horm Res 2002;57: 411-434.

89. Karim A, Ranney R, Zagarella J, Maibach HI. Oxandrolone disposition and metabolism in man. Clin Pharmacol Ther 1973; 14:862-869.
90. Crock P, Werther GA, Wettenhall HN. Oxandrolone increases final height in turner syndrome. J Paediatr Child Health 1990;26: 221-224.

91. Wilson DM, McCauley E, Brown DR, Dudley R. BioTechnology General Corporation Cooperative Study Group. Oxandrolone therapy in constitutionally delayed growth and puberty. Pediatrics 1995;96:1095-1100.

92. Auerbach HS, Williams M, Kirkpatrick JA, Colten HR. Alternate-day prednisone reduces morbidity and improves pulmonary function in cystic fibrosis. Lancet 1985;2:686-688.

93. Rosenstein BJ, Eigen H. Risks of alternate-day prednisone in patients with cystic fibrosis. Pediatrics 1991;87:245-246.

94. Eigen H, Rosenstein BJ, FitzSimmons S, Schidlow DV. A multicenter study of alternate-day prednisone therapy in patients with cystic fibrosis. Cystic fibrosis foundation prednisone trial group. J Pediatr 1995;126:515-523.

95. Lai HC, Kosorok MR, Allen DB, FizSimmons SC, Rosenstein BJ, Campbell PW, Eigen HH, Farrell PM. Long-term growth evaluation in children with cystic fibrosis with history of regular use of alternate-day prednisone therapy. Pediatr Pulmonol 1999;28:297.

96. Vaisman N, Clarke R, Rossi M, Goldberg E, Zello GA, Pencharz $\mathrm{PB}$. Protein turnover and resting energy expenditure in patients with undernutrition and chronic lung disease. Am J Clin Nutr 1992;55:63-669.

97. Hardin DS, LeBlanc A, Lukenbaugh S, Para L, Seilheimer DK. Proteolysis associated with insulin resistance in cystic fibrosis. Pediatrics 1998;101:433-437.

98. Harin DS, Ellis K, Dyson M, Rice J, McConnell R, Seilheimer DK. Growth hormone decreases protein catabolism in children with cystic fibrosis. J Clin Endocrinol Metab 2001;86:44244428.

99. Serri O, St-Jacques P, Sartippour M, Renier G. Alterations of monocyte function in patients with growth hormone $(\mathrm{GH})$ deficiency: effect of substitutive GH therapy. J Clin Endocrinol Metab 1999;84:58-63.

100. Holt TL, Ward LC, Francis PJ, Isles A, Cooksley WGE, Shepherd RW. Whole body protein turnover in malnourished cystic fibrosis patients and its relationship to pulmonary disease. Am J Clin Nutr 1985;41:1061-1066.

101. Bonefield TL, Panuska JR, Konstan NM. Inflammatory cytokines in cystic fibrosis lungs. Am J Respir Crit Care Med 1995; 152:2111-2116.

102. Elborn JS, Cordon SM, Western PJ, MacDonald IA, Shale DJ. Tumour necrosis factor, $\alpha$, resting energy expenditure and cachexia in cystic fibrosis. Clin Sci 1993;85:563-568. 